Науковий вісник НлТУ України Scientific Bulletin of UNFU http://nv.nltu.edu.ua

https://doi.org/10.15421/40290324

Article received 25.03.2019 p.

Article accepted 25.04.2019 p.

УДК 004.048
ISSN 1994-7836 (print)

ISSN 2519-2477 (online)

$@$ Correspondence author

O. B. Vovk

olena.b.vovk@lpnu.ua

О. Б. Вовк, В. В. Войцеховська, О. Я. Загорецька, Л. І. Лесик, В. З. Пашкевич, А. В. Симак

Національний університет "Львівська політехніка", м. Львів, Україна

\title{
АЛГОРИТМ ВТОРИННОГО ПЕРЕРОБЛЕННЯ ПАПЕРУ В УМОВАХ ПРИРОДО-РЕСУРСНОГО ГОСПОДАРСТВА
}

Сьогодні в Україні виникла життєва необхідність перероблення різних типів відходів та доведення показників такого перероблення до середніх у Європі. Це важливо і погляду економіки, екології і зору гігієни і тощо. Генерування великої кількості різних видів паперового сміття потребує формування організованого рециклінгу та підвищення його ефективності способом впровадження замкнутого циклу перероблення та повторного використання. Циркулярна економіка забезпечує максимальну ефективність кожного процесу в життєвому циклі товару або послуги та багаторазове використання відходів. Тому організований рециклінг є одним з її пріоритетних напрямів. Сьогодні використовують багато різних видів паперу, а об'єм деревинної сировини зменшується. Світове споживання паперу зросло на 400 \% за останні 40 років. Зараз у світі споживається близько 300 млн т паперу на рік. У целюлозно-паперовій промисловості в усьому світі щорічно використовують близько 4 млрд дерев або 35 \% від загального обсягу зрубаних дерев. Наприклад, перероблення однієї тонни газетного паперу економить близько 1 т деревини, а перероблення 1 т паперу для друку або для копіювальних пристроїв - майже 2 т деревини. 3 огляду на це, вкрай необхідним $є$ розуміння основних процесів перероблення паперу та способів ефективного його запровадження на підприємствах та в організаціях. Зроблено спробу з'ясувати, окреслити основні підходи в процесі перероблення паперу як вторинної сировини та сформувати узагальнену класифікацію типів паперу, що придатний для перероблення. Визначено типи паперу, які не підлягають переробленню. Розглянуто основні етапи перероблення паперу. Визначено основні переваги та недоліки процесу перероблення паперу як вторинної сировини.

Ключові слова: папір; вторинна сировина; етапи перероблення; класифікація паперу.

Вступ. Використаний папір чи макулатура (відходи різного типу паперу чи картону) - це вторинна сировина, що використовують у повторному виробництві паперу чи картону. Зокрема макулатуру часто використовують як вторинну сировину підприємства різного роду діяльності - від виготовлення туалетного паперу, горбкуватих прокладок до теплоізоляційних матеріалів, будівельних матеріалів та інших продуктів, до складу яких входить целюлоза.

Обсяг використання макулатури в стандартних різновидах картонно-паперової продукції найчастіше визначають рівнем наявних цін на деревну масу і целюлозу, а також попитом на зазначену продукцію. Від початку свого існування вона була джерелом заробітку для людей (підприємств), які збирали та продавали таку вторсировину зацікавленим заводам (мануфактурам/виробництвам). Варто зауважити, що налагодження такого бізнесу охоплює ретельне продумування всіх аспектів і механізмів, що дасть змогу отримувати достатньо хороший дохід особі (підприємству), які впроваджують такі процеси у своїй роботі.

Наша робота стосується, власне, огляду таких процесів, способів їх вдосконалення та доцільності їх використання у циркулярній економіці окремого підприємства чи організації.

Аналіз останніх досліджень та публікацій. Загалом, до будь-яких відходів можна застосовувати дії, зображені на рис. 1.

Знищення - процес ліквідації відходів способом захоронення чи спалювання (Vidkhody, 2019; Vovk, 2018).

Інформація про авторів:

Вовк Олена Борисівна, канд. техн. наук, доцент, кафедра систем штучного інтелекту. Email: olenavovk@gmail.com; https://orcid.org/0000-0001-5523-0901

Войцеховська Вікторія Вікторівна, канд. екон. наук, доцент, кафедра економіки підприємства та інвестицій. Email: viktoriia.v.voitsekhovska@lpnu.ua

Загорецька Олена Ярославівна, канд. екон. наук, доцент, кафедра економіки підприємства та інвестицій. Email: zagoreckao@gmail.com; https://orcid.org/0000-0002-2825-7997

Лесик Лілія Іванівна, канд. екон. наук, доцент, кафедра економіки підприємства та інвестицій. Email: lilia.lesyk@gmail.com; https://orcid.org/0000-0003-1324-9027

Пашкевич Володимир Зеновійович, канд. екон. наук, доцент, кафедра електронних засобів та інформаційно-комп'ютерних технологій. Email: pashkevitch.volodymyr@gmail.com; https://orcid.org/0000-0002-6849-652X

Симак Анастасія Валеріївна, канд. екон. наук, доцент, кафедра економіки підприємства та інвестицій. Email: anastasiia.v.symak@Ipnu.ua; https://orcid.org/0000-0001-6371-2206

Цитування за ДСТУ: Вовк О. Б., Войцеховська В. В., Загорецька О. Я., Лесик Л. І., Пашкевич В. З., Симак А. В. Алгоритм вторинного перероблення паперу в умовах природо-ресурсного господарства. Науковий вісник НЛТУ України. 2019, т. 29, № 3. С. 114-119.

Citation APA: Vovk, O. B., Voytsekhovska, V. V., Zagoretska, O. Ya., Lesyk, L. I., Pashkevych, V. Z., \& Symak, A. V. (2019). Algorithm for secondary processing of paper in the conditions of market economy. Scientific Bulletin of UNFU, 29(3), 114-119. https://doi.org/10.15421/40290324 
Утилізація (від лат. unilis - корисний) охоплює пряме повторне використання та використання після перероблення.

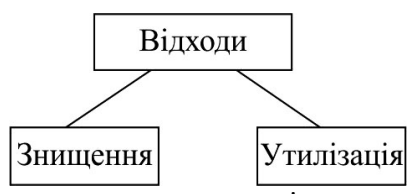

Рис. 1. Загальна схема поводження з відходами

Пряме повторне використання (англ. reusing) - використання відходів без попереднього чи додаткового перероблення у тих випадках, коли воно технічно можливе, технологічно необхідне та дозволяється законодавством. Це може бути повторне використання одягу (після дезінфекції та (чи) термічної обробки) або скляної тари (якщо вона неушкоджена та підлягає повторному використанню).

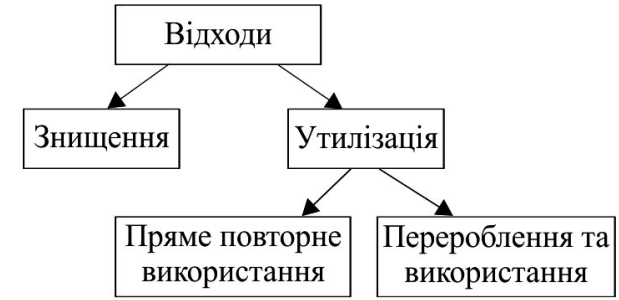

Рис. 2. Шляхи поводження з відходами на стадії утилізації

Перероблення та використання товарів (продукції), виконання робіт, надання послуг, що включає повторне використання відходів, поділяється на:

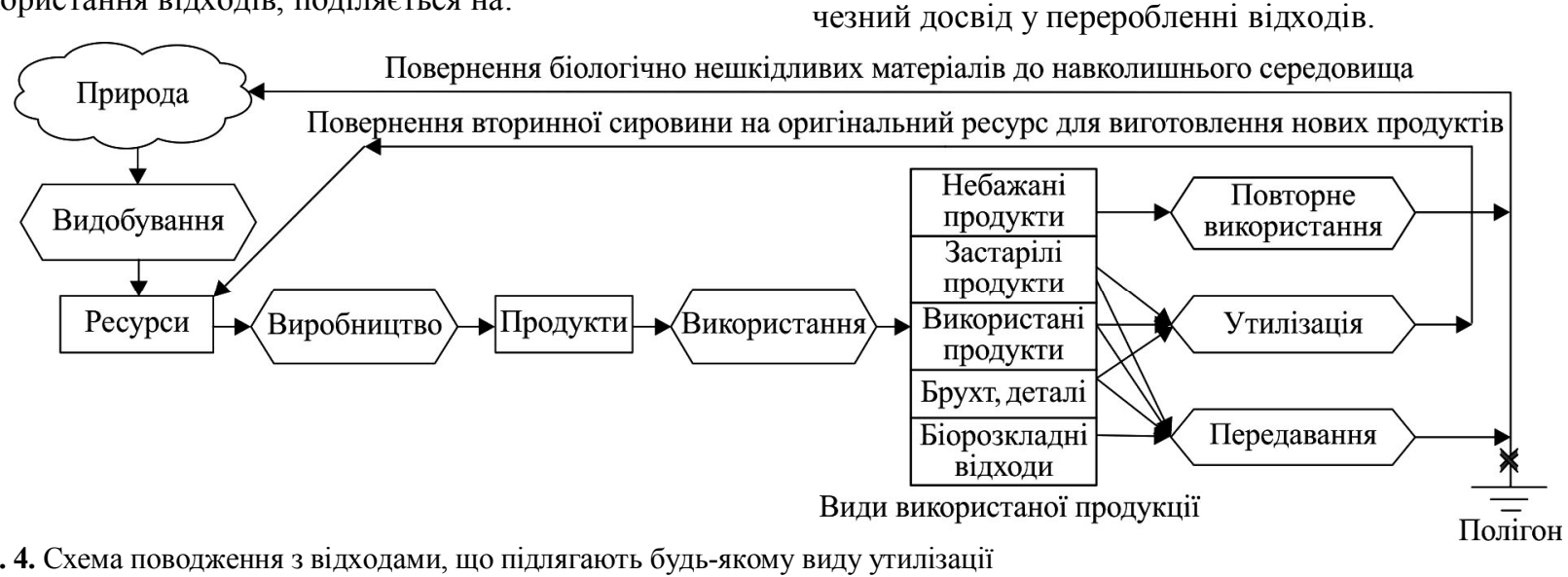

Рис. 4. Схема поводження з відходами, що підлягають будь-якому виду утилізації

Поєднання продукування відходів та знищення ресурсів деревини в регіоні - це ще одна величезна проблема людства. У світі щорічно вирубують сотні тисяч дерев, зокрема, задля виробництва паперу. Після першого використання макулатуру відправляють у сміття. Вартий уваги також той факт, що зараз на одну людину припадає величезна кількість паперу. Окрім цього, приватні офіси і державні установи за певний період накопичують неймовірний обсяг паперу абсолютно різної якості.

Якби не існувало вторинного перероблення сировини, то запасів деревини на нашій планеті просто не вистачило б для постійного виробництва в різних галузях. Весь цей папір накопичується в архівах і на його зберігання накладаються певні часові межі, а після цього його можна використовувати для вторинного перероблення. Утилізація архівів способом перероблення паперу допомагає зберегти навколишнє середовище регіону, водночас забезпечуючи його необхідною кількістю паперу.
- pециикінг (англ. recycling) - діяльність, яка полягає у поводженні з відходами з метою їх безпечного знищення або забезпечення повторного їх використання в народному господарстві як сировини, енергії, виробів та (чи) матеріалів;

- регенерація - процес повернення відходів у виробничий цикл після відповідної підготовки;

- рекуперація - процес витягу корисних компонентів з відходів для їх повторного застосування (Retsyklinh, 2019).

Графічно цей поділ представлено на рис. 3.

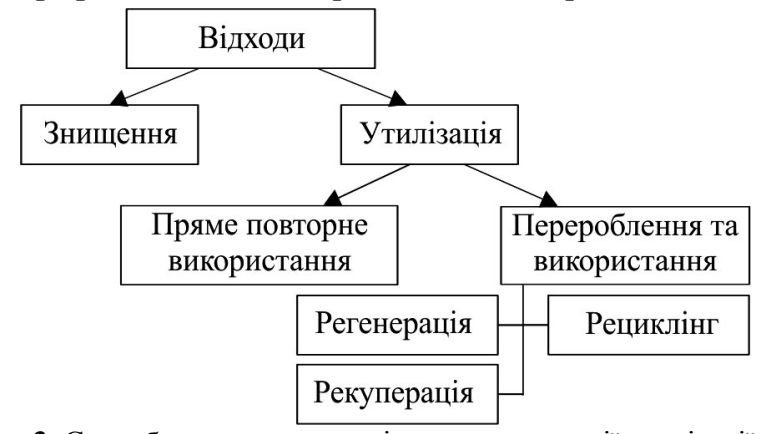

Рис. 3. Способи поводження з відходами на стадії утилізації $з$ підпроцесами

Загальну схему запровадження такого підходу до поводження з відходами, що підлягають будь-якому виду утилізації, подано на рис. 4. Утилізація відходів $є$ серйозною задачею для людства. В Америці і Європі поширюються технології, що допомагають максимально ефективно використовувати вторинну сировину. Україна в цій сфері поки що відстає, хоча країна має величезний досвід у переробленні відходів. 
Виготовлення паперу з вторсировини проходить такі етапи: організаційний і технологічний. На організаційному етапі насамперед маємо розуміти, навіщо потрібно переробляти папір. Раніше у країнах пострадянського простору дохідливо пояснювали, чому життєво необхідно здавати макулатуру, картон та іншу сировину на перероблення. Сьогодні держава приділяє менше уваги просвітницькій роботі, суспільство не збирає газети і журнали, щоб здати їх на перероблення, хоча необхідність збереження навколишнього середовища не тільки не зменшується, а й постійно зростає через збільшення проблем в екології.

Розкладання паперу залежно від його виду в природі відбувається у часових межах, що подано у таблиці.

Таблиця. Розкладання паперу залежно від його виду в природі

\begin{tabular}{|l|c|}
\hline \multicolumn{1}{|c|}{ Вид паперу } & Термін розкладання \\
\hline Папір газетний & Від 1 місяця до 1 року \\
\hline Папір звичайний (офісний) & 2 роки \\
\hline Картон & 2 місяці \\
\hline Картонні коробки & до 1 року \\
\hline Картонне пакування з-під молока & 5 років \\
\hline
\end{tabular}

Існує кілька причин, через які необхідно утилізувати або переробляти папір чи картон.

По-перше, виробництво паперу здатне сильно нашкодити навколишньому середовищу, особливо на перших етапах виробничого процесу. У навколишнє середовище потрапляє безліч токсинів (формальдегід, діоксид хлору та інші). Перероблення макулатури - значно менш небезпечний для екології процес, в атмосферу потрапляє менше шкідливої хімії і токсинів. Згідно $з$ даними американських екологів, у процесі перероблення відходів забруднення води і повітря знижується на 35 і 74 \% відповідно (Berkli, 2019).

По-друге, перероблення паперу знижує обсяг споживаної енергії підприємствами чи виробництвами. За різними оцінками, правильно організований процес перероблення відходів дає змогу скоротити обсяг використовуваної електроенергії від 40 до $65 \%$.

По-третє, організація процесу перероблення макулатури загалом і картону зокрема сприяє зниженню обсягів вирубки лісів, що $є$ надзвичайно важливо для України.

За статистикою (Lykho, 2019), за останні кілька десятиліть людство почало використовувати більше паперу в 4-5 разів. Це означає, що щорічно ми споживаємо мільйони тонн паперу. Понад третину всіх вирубаних дерев на планеті спрямовують на целюлозно-паперові фабрики, причому тільки $16 \%$ із загальної кількостіце дерева, спеціально вирощені для промисловості.

Після використання паперу, його необхідно зібрати. Зазвичай збирати його можна і навіть потрібно відповідно до типу. Звичайний побутовий папір переробляється практично весь. Проте з'ясуємо, який саме папір підлягає, а який не підлягає переробленню.

Класифікація паперу за різними категоріями залежно від типу:

• типи паперу, що добре піддаються переробленню:

- картон;

- цупкий папір (>100 г/ м $\left.^{2}\right)$;

- газети;

- журнали;

- рекламні буклети, невеликі брошури;

- конверти (без пластикових вікон);

папір для копіювальних апаратів $\left(80\right.$ г/ $\left.\mathrm{M}^{2}\right)$;

газетний папір;

- інші типи паперу, що є дещзо більш складнішими в процесі перероблення і менше приймаються на перероблення:
- $\quad$ подрібнений папір - його приймають тоді, коли підприємство має спеціалізоване устаткування для такого перероблення;

- папір для нотаток - його приймають тоді, коли на підприємстві є можливість видаляти клей з паперу;

- пакувальний папір - деякі підприємства приймають звичайний обгортковий папір, якщо він не має таких включень; як: блискучі частинки, липка стрічка або інші прикраси;

- зазвичай не підлягає переробленню:

брудний або мокрий папір;

коробки для піщи;

паперові стакани;

обгортки кондитерської продукції, конфетті;

серветки;

туалетний папір;

паперові рушники;

копірка.

Однак чисті серветки, туалетний папір, паперові рушники можна використовувати для виробництва паперу ручної роботи. Оскільки методики перероблення макулатури на устаткуванні, що використовують фахівці, залежать від якості початкової сировини і вимог до кінцевого продукту, тому спочатку весь використаний папір необхідно зібрати і впорядкувати. Зокрема розсортувати папір на: звичайний; папір з графікою; крафт-папір; картон.

Наступний етап - технологічний. Власне, саме на цьому етапі відбувається процес перероблення макулатури. Технологія перероблення макулатури залежить від матеріалу, що переробляється, і кінцевого продукту. Після правильного оброблення, практично всі типи паперу піддаються переробленню і їх можна використовувати для отримання нового паперу. Деякий папір складніше переробляти, оскільки він містить сторонні елементи. Наприклад, конверти з пластиковими вікнами не піддаються переробленню одразу - спочатку пластик необхідно видалити. Папір із пластиковим покриттям також може стати проблемою, але в будь-якому випадку необхідно уточнювати можливість перероблення на відповідних виробництвах, що мають спеціальне обладнання.

Загалом технологічний процес перероблення макулатури складається 3 декількох послідовних етапів. Щоб отримати якісний перероблений папір, сировину, спочатку потрібно знебарвити - видалити стару фарбу і друк. Варто ще раз наголосити, що з неочищених від фарби волокон можна виробляти папір або інші продукти тільки низької якості, тому необхідність таких робіт визначається кінцевою метою перероблення.

Далі виконується розпуск на волокна, який відбувається в гідророзбивачі, в якому макулатура крутиться у водному середовищі. На цьому кроці відбувається також відділення включень. Після його завершення суспензія містить волокна і нерозбиті частинки макулатури. Потім відбувається очищення суспензії макулатурної маси від сторонніх домішок.

Важкі домішки видаляються завдяки обертанню в барабані, коли мікроскопічні домішки піску, скла, скріпок тощо, осідають у сміттєзбірнику, а легкі - за допомогою пропускання маси через сито. Під час перероблення картону і паперу проблематичної структури застосовують термомеханічне оброблення для нейтралізації дії місткості клею, парафіну, воску тощо. Далі паперова маса дорозпускається за допомогою розмелювання на млині та піддається тонкому очищенню. 
Нижче подано алгоритм перероблення паперу як вторинної сировини (рис. 5).

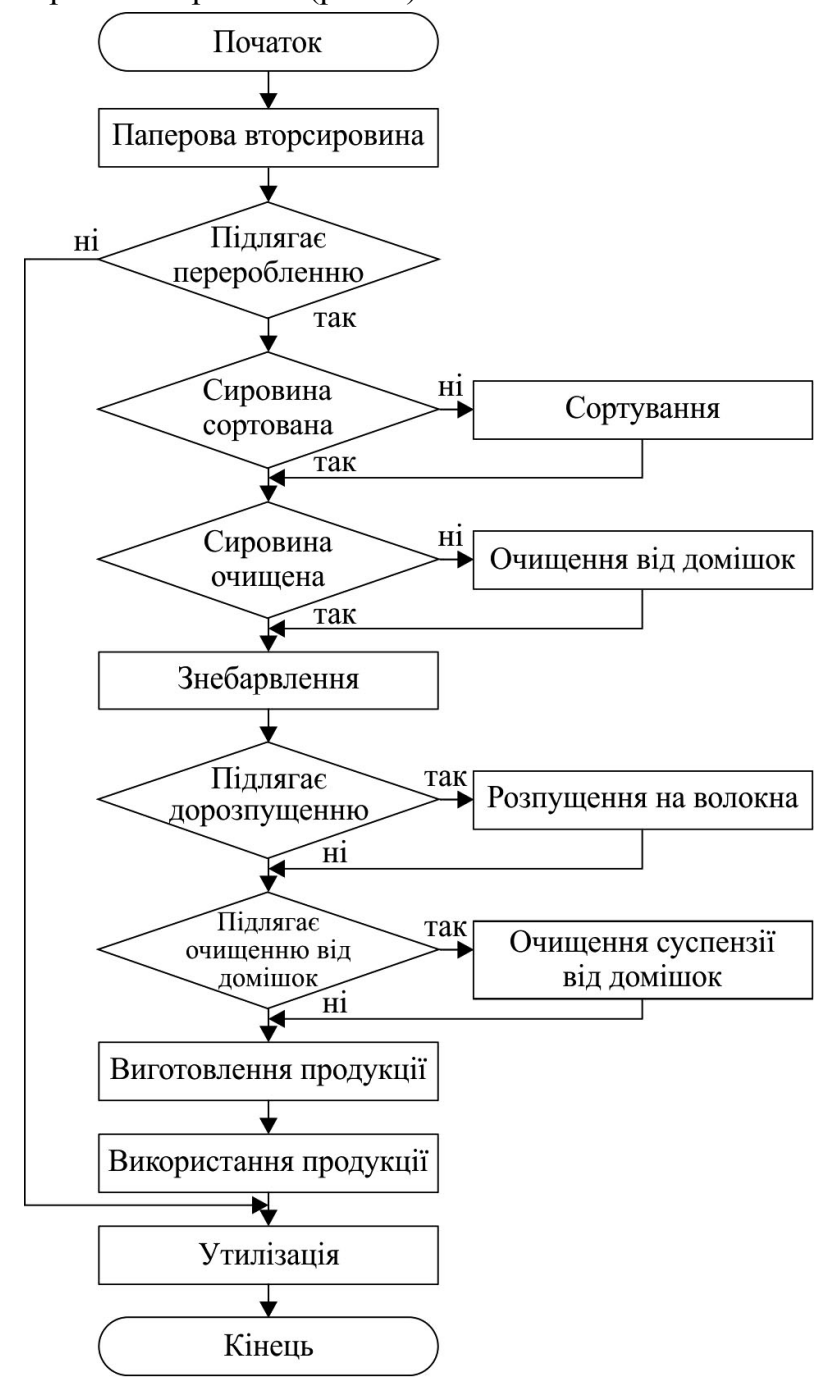

Рис. 5. Узагальнений алгоритм перероблення паперової вторсировини

Проте варто пам'ятати, що процес перероблення пресованого картону дещо відрізняється від процесу перероблення паперу: сировина повинна пройти температурне оброблення, за допомогою якого з картону видаляється клей, віск й інші місткості. На завершальному етапі отримана сировина розпускається на дрібні елементи і піддається найретельнішому очищенню.

Хоча перероблення макулатури є багатоетапним процесом, мета якого полягає у відновленні паперового волокна та (або) інших компонентів паперу (таких, як мінеральні наповнювачі), сучасні методики перероблення макулатури можна назвати ідеальними. Застосовувані на комбінатах і заводах методи дають змогу переробляти паперову вторсировину декілька разів (від 3-х до 7 разів залежно від обладнання).

Окрім цього, варто пам'ятати, що кожна наступна робота зі сировиною знижує довжину волокон, внаслідок вони стають непридатними для виробництва якісного паперу, картону або будь-яких інших товарів. Згодом папір жовтіє і зазвичай для виробництва нових паперових виробів вторинне волокно змішують 3 новим. Саме тому людство поки не може повністю відмовитися від виробництва нового паперу, хоча вартість перероблення відходів і їх вторинного використання постійно знижується завдяки розвитку нових технологій.
За правильного проектування сучасних виробництв iз перероблення макулатури, підприємства розглядають комплекс показників, які забезпечують ефективну утилізацію відходів - це повний спектр технологій: від створення виробництва та експлуатації до виведення 3 обігу. Згідно зі статистичними даними, деякі підприємства, що використовують раціональні підходи під час перероблення паперових відходів, отримують прибуток до 50 тис. дол. на рік.

Вище ми розглядали переваги перероблення паперової вторсировини. Однак $є$ й обмежувальні моменти. Один із них - це забруднення повітря і води. Як вже зазначали, промислове виробництво паперу з вторсировини негативно впливає на навколишнє середовище на початковому етапі отримання і оброблення сировини, i істотно менше впливає на наступних етапах. Проте під час первинного виробництва паперу в повітря і воду потрапляють високотоксичні хімічні речовини, такі як: толуол, метанол, діоксид хлору, соляна кислота і формальдегід, які отримуються під час всього процесу виробництва паперу. Окрім цього, створення переробленого паперу потребує менше хімічних речовин і відбілювачів, ніж створення нового паперу. Однак варто зазначити, що під час виробництва вторинного паперу може утворюватися більше шлаку. За оцінкою Агентства США 3 охорони навколишнього середовища (Sonrecycling, 2019), під час перероблення макулатури, порівняно $з$ виробництвом нового паперу, забруднення води знижується на третину, а забруднення повітря зменшується на дві третини.

Використання переробленої макулатури знижує споживання енергії, проте 3 приводу конкретних значень економії ведуться суперечки. Державне управління енергетичної інформації США (Energy, 2016) стверджує, що економія енергії завдяки переробленню макулатури, порівняно 3 виробництвом паперу з целюлози, знижує витрати енергії на 40 \%, тоді як Бюро міжнародної рециркуляції (Facts, 2019) стверджує, що витрати енергії знижуються на 65 \%. Проте на отримання паперової маси під час перероблення паперу фактично витрачається більше твердого палива, ніж на отримання целюлози через крафт-процеси, коли велика частина енергії споживається під час спалювання деревних відходів (кори, коренів, відходів деревообробного типу) i побічних продуктів лігніну (чорного лугу).

Ще одним негативним моментом під час створення первинного паперу, порівняно з вторинним переробленням використаного паперу, є вирубка лісів. Світове споживання паперу зросло на $400 \%$ за останні 40 років. Зараз споживається близько 300 млн т паперу на рік. Переважно для виробництва паперу використовують первинну целюлозу, на перероблену макулатуру припадає $38 \%$ світового обсягу поставок волокна, на недеревинні волокна з рослин, таких як: конопля або кенафа, припадає $7 \%$. 3 дерев, спеціально вирощених у розсадниках, виготовляється $16 \%$ світового обсягу целюлози. Основну частину деревини для виготовлення паперу отримують 3 вторинного лісу. 3 прадавніх лісів продукується менше $9 \%$ целюлози. Розсадники можуть частково задовольняти попит на деревину, однак вони не можуть забезпечити існування різноманітних рослин і тварин, як у природних лісах.

На рис. 6 зображено загальну схему виробництва паперу з первинної та вторинної сировини. 


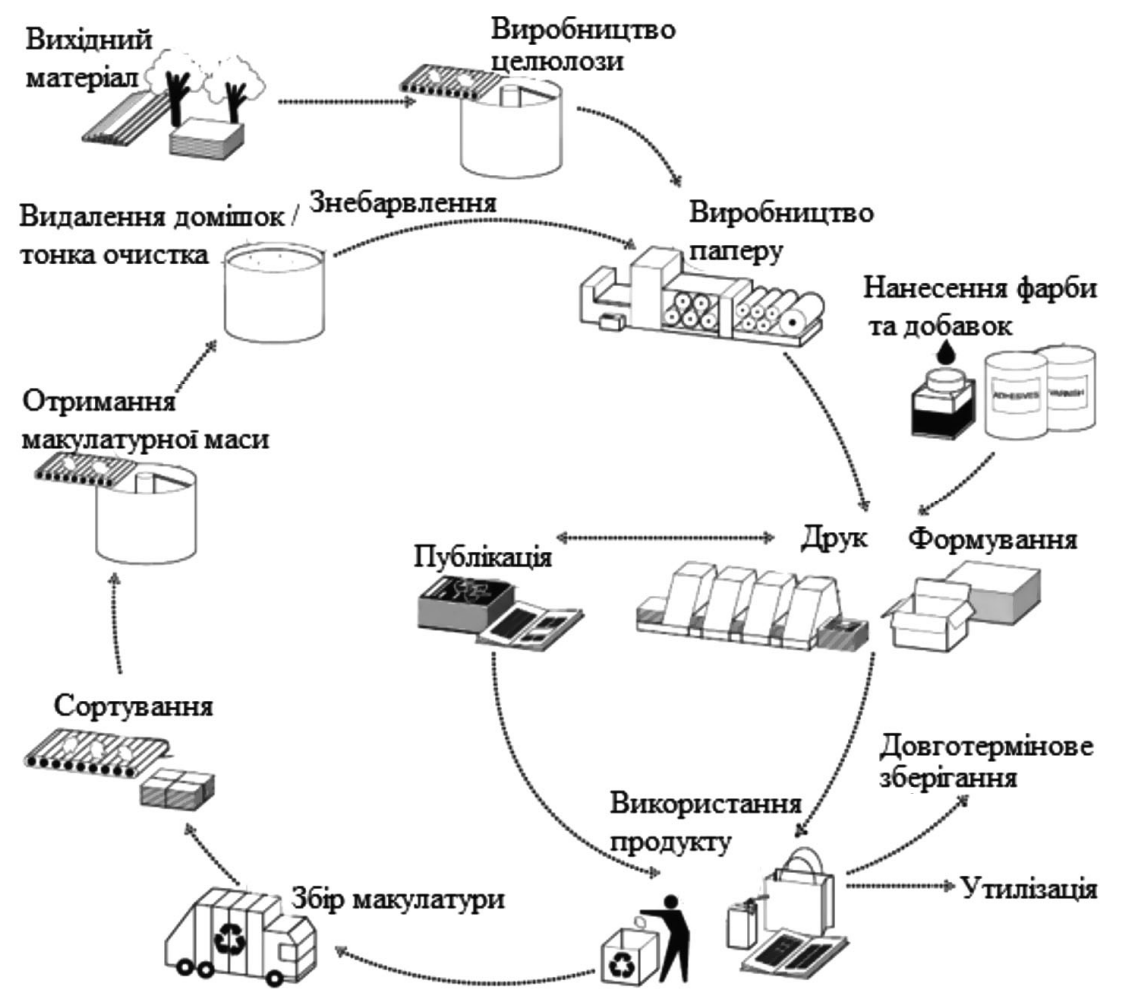

Рис. 6. Загальна схема виробництва паперу (з первинної та вторинної сировини)

Висновки. Незважаючи на все, ще є великі енерго- i ресурсовитрати під час перероблення макулатури. Переваги для навколишнього середовища загалом та будьякого регіону зокрема є очевидними.

За допомогою вторинного перероблення картону і паперу можна отримати продукцію, яка за якістю не поступається тій, яку виготовляють 3 целюлози. Тому пункти прийому макулатури, дуже популярні в колишні часи, знову почали відновлювати свою роботу. До прикладу, перероблення однієї тонни газетного паперу економить близько 1 т деревини, а перероблення 1 тонни більш якісного паперу (для друку або для копіювальних апаратів) - майже 2 т деревини.

В умовах ринкової економіки і глобального підходу до покращення екологічної та економічної ситуації в регіоні, запровадження підходів щодо перероблення паперової вторинної сировини, де $\epsilon$ великий паперообіг, $\epsilon$ абсолютно доцільним та економічно обгрунтованим. I навіть якщо отримати особливу матеріальну вигоду 3 макулатури не вдасться, то принести користь суспільству і зберегти кілька сотень дерев регіону можливо.

\section{Перелік використаних джерел}

Berkli. (2019). Dani pro rozvytok mist ta zelenykh zon Ukrainy peredani dlia vyvchennia u Kaliforniiskyi universytet v Berkli. Retri- eved from: https://www.unian.ua/ecology/10319535-dani-prorozvitok-mist-ta-zelenih-zon-ukrajini-peredani-dlya-vivchennya-ukaliforniyskiy-universitet-v-berkli.html. [In Ukrainian].

Energy. (2016). Energy Explained: Energy information for a wide audience. Energy Information Administration. Retrieved from: https://www.eia.gov/beta/international/data/browser/\#/?c=4100000 $002000060000000000000 \mathrm{~g} 000200000000000000001 \& \mathrm{vs}=\mathrm{INTL} .4$ 4-1-AFRC-QBTU.A\&vo $=0 \& \mathrm{v}=\mathrm{H} \&$ end $=2016$

Facts. (2019). Recycling Facts. Retrieved from: https://bir.org/industry/paper/?locale=en US

Lykho. (2019). Ekolohichne lykho: Vynyshchennia lisiv v Ukraini. [In Ukrainian]. Retrieved from: https://www.unian.ua/ecology/ 1272491-ekologichne-liho-vinischennya-lisiv-v-ukrajini.html. [In Ukrainian].

Retsyklinh. (2019). Poniattia retsyklinhu. Retrieved from: https://ru.wikipedia.org/wiki/Pererabotka otkhodov\#Retsyklynh. [In Ukrainian].

Sonrecycling. (2019). General information and statistic sonrecycling. Retrieved from: https://search.epa.gov/epasearch/?querytext= paper\&areaname $=\&$ areacontacts $=$ \&areasearchurl $=$ \&typeofsearch $=$ epa\&result template $=2$ col.ftl\#I

Vidkhody. (2019). Zakon Ukrainy pro vidkhody. Retrieved from: http://zakon2.rada.gov.ua/laws/show/187/98-vr. [In Ukrainian].

Vovk, O. B. (2018). Formation of systems approach to information system of supervision of waste. Scientific Bulletin of UNFU, 28(3), 142-146. https://doi.org/10.15421/40280329

\section{O. B. Vovk, V. V. Voytsekhovska, O. Ya. Zagoretska, L. I. Lesyk, V. Z. Pashkevych, A. V. Symak Lviv Polytechnic National University, Lviv, Ukraine}

\section{ALGORITHM FOR SECONDARY PROCESSING OF PAPER IN THE CONDITIONS OF MARKET ECONOMY}

Today in Ukraine there is a vital need to process various types of waste and bring the indicators of such processing to the average in Europe. It is important in terms of economy, ecology, hygiene, etc. Generating of a large number of different types of paper waste requires the formation of organized recycling and increasing its efficiency through the introduction of a closed processing cycle and the use of products obtained by such processing. The circular economy ensures maximum efficiency of each process in the life cycle of a product or service, and reuse of waste. The combination of waste production and the destruction of wood resources in the region is yet another huge problem of humanity. Therefore, organized recycling is one of its priorities. Today, many different types of paper are used, and the volume of wood raw materials is decreasing. Global paper consumption has grown by 400 percent in the last 40 years. Nowadays, about 300 million tons of paper is consumed per year. In the pulp and paper industry worldwide, about 4 billion trees are used annually, which is 35 percent of the total volume of logged trees. Recycling 1 ton of newsprint paper saves about 1 ton 
of wood, and processing 1 ton of paper for printing or copiers saves almost 2 tons of wood. Waste utilization is a serious challenge for humanity. In America and Europe, technologies that allow the most efficient use of recycled materials are distributed. Ukraine is lagging behind in this area, although the country has vast experience in recycling waste. Considering this, it becomes extremely necessary to understand the basic processes of paper processing and the ways of its effective introduction at enterprises and organizations. The article attempts to clarify and identify the main approaches in the process of recycling paper as recycled materials, to form a generalized classification of paper types suitable for recycling. The types of paper that cannot be recycled are identified. Considering the main stages of paper in the article, we identified the main advantages and disadvantages of recycling paper as recyclable materials.

Keywords: paper; recycled materials; processing steps; paper classification. 